\title{
Measurement of Hepatic Glucose Output, Krebs Cycle, and Gluconeogenic Fluxes by NMR Analysis of a Single Plasma Glucose Sample
}

\author{
J ohn G. J ones,* Rui A. Carvalho,† Byron Franco,* A. Dean Sherry,*Æ and Craig R. Malloy*,§ \\ *Mary Nell and Ralph B. Rogers Magnetic Resonance Center, Department of Radiology, University of Texas \\ Southwestern Medical Center, Dallas, Texas 75235; †Department of Biochemistry, University of Coimbra, \\ Coimbra, Portugal; łDepartment of Chemistry, University of Dallas, Richardson, Texas; \\ and §Department of Veterans Affairs Medical Center, Dallas, Texas
}

Received April 20, 1998

\begin{abstract}
${ }^{13} \mathrm{C}$ and ${ }^{1} \mathrm{H}$ NMR spectroscopy of plasma glucose was used to resolve the isotopomer contributions from tracer levels of $\left[1,6^{-13} \mathrm{C}_{2}\right]$ glucose, a novel tracer of glucose carbon skeleton turnover, and $\left[\mathrm{U}-{ }^{13} \mathrm{C}\right]$ propionate, a tracer of hepatic citric acid cycle metabolism. This allowed simultaneous measurements of hepatic glucose production and citric acid cycle fluxes from the NMR analysis of a single plasma glucose sample in fasted animals. Glucose carbon skeleton turnover, as reported by the dilution of $\left[1,6-{ }^{13} \mathrm{C}_{2}\right]$ glucose, was $56 \pm$ $2 \mu \mathrm{mol} / \mathrm{kg} / \mathrm{min}$ in the presence of labeling from $\left[\mathrm{U}-{ }^{13} \mathrm{C}\right.$ ]propionate and $53 \pm 4 \mu \mathrm{mol} / \mathrm{kg} / \mathrm{min}$ in its absence. Therefore, as expected, the labeling contributions from $\left[\mathrm{U}-{ }^{13} \mathrm{C}\right]$ propionate metabolism did not have a significant effect on the measurement of glucose turnover. For the group infused with both tracers, citric acid cycle flux estimates from the analysis of glucose C2 isotopomer ratios were consistent with those from our recent experiments where only $\left[\mathrm{U}-{ }^{13} \mathrm{C}\right.$ ]propionate was infused, verifying that the presence of $\left[1,6-{ }^{13} \mathrm{C}_{2}\right]$ glucose did not interfere with these measurements. This integrated analysis of hepatic glucose output and citric acid cycle fluxes from plasma glucose isotopomers yielded a noninvasive esti mate of hepatic citrate synthase flux of $74 \pm 12 \mu \mathrm{mol} / \mathrm{kg} / \mathrm{min}$ for 24-h fasted rats. $\odot 1998$ Academic Press
\end{abstract}

A continual supply of glucose is essential for the proper function of many tissues and organs, notably erythrocytes and the brain. Because of this central role of glucose in energy metabolism and its relevance to a broad range of disease states, numerous methods have been developed to measure the rate of whole-body glu- cose metabolism and synthesis (1-9). These methods assume a constant freely exchanging pool of glucose in the body and a constant rate of glucose synthesis which is balanced by an equal rate of utilization. Since glycolysis is responsible for the bulk of whole-body glucose metabolism, tracers of glucose utilization are usually designed with this pathway in mind $(3,8-10)$. Because there are several substrate cycles that interconvert plasma glucose with glycolytic intermediates, the glucose tracer must be irreversibly degraded by glycolysis to report a true dilution by endogenous glucose production. Since glucose metabolism is usually defined as the glycolytic cleavage of the hexose carbon skeleton, tracers are selected to reflect glucose metabolism to the level of aldolase or bel ow. Classical radioisotope tracers of glucose turnover, $\left[3-{ }^{3} \mathrm{H}\right]-,\left[5-{ }^{3} \mathrm{H}\right]-$, and $\left[6-{ }^{3} \mathrm{H}\right]$ glucose are all degraded at or below the level of triose phosphates, and the same is true for their stable deuterated counterparts. [U- ${ }^{13} \mathrm{C}_{6}$ ] Glucose is a true carbon skel eton tracer and is increasingly being used for whole-body glucose utilization measurements $(2,3,7,11)$.

In addition to direct infusion of a tracer, plasma glucose can also be labeled by metabolism of a labeled gluconeogenic precursor such as lactate or propionate (1218). The labeling pattern in carbons 1,2 , and 3 of glucose reflect that of the labeled phosphoenolpyruvate (PEP) ${ }^{1}$ precursor, providing flux information on the component pathways of PEP production from the hepatic citric acid cycle $(13,16,18)$. If the labeling in glucose derived from PEP can be distinguished from the labeling in glucose used for measuring glucose utilization, the components of gluconeogenic flux as well as total glucose output can be

\footnotetext{
${ }^{1}$ Abbreviations used: PEP, phosphoenolpyruvate; PK, pyruvate kinase; ME, malic enzyme; CC, Cori cycle.
} 


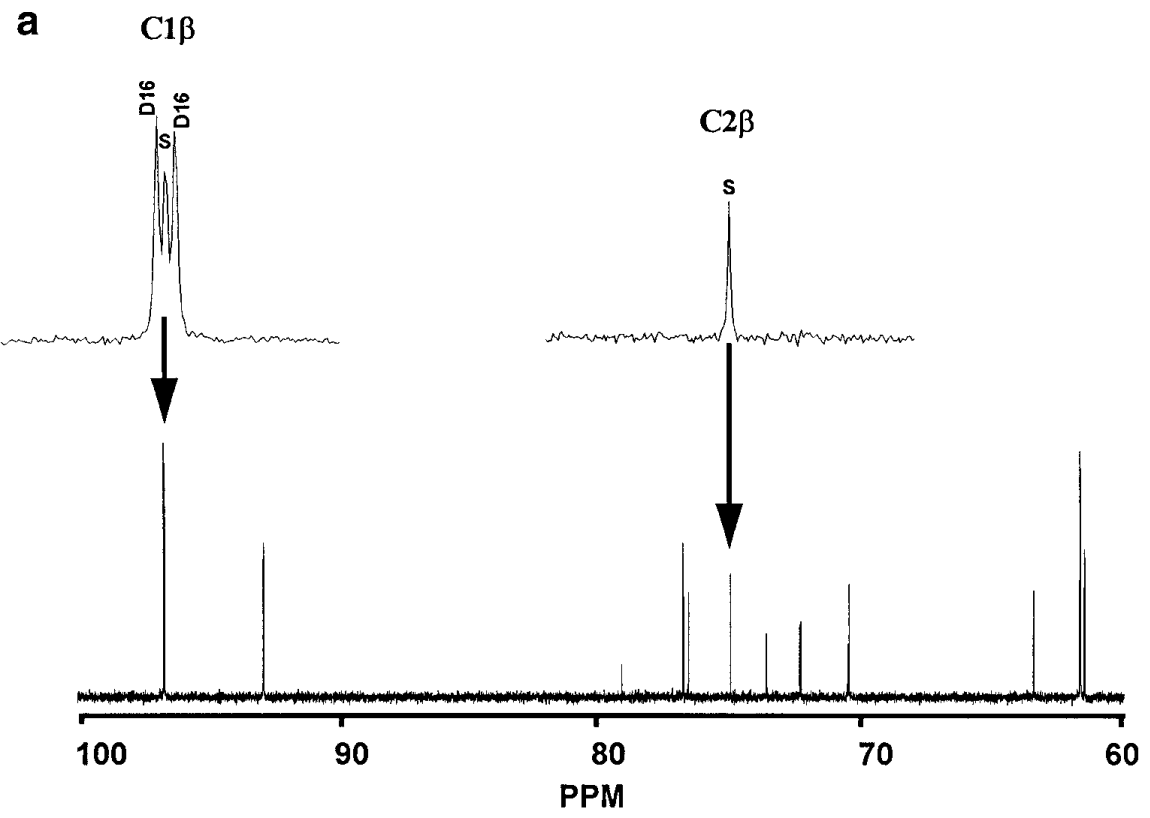

b

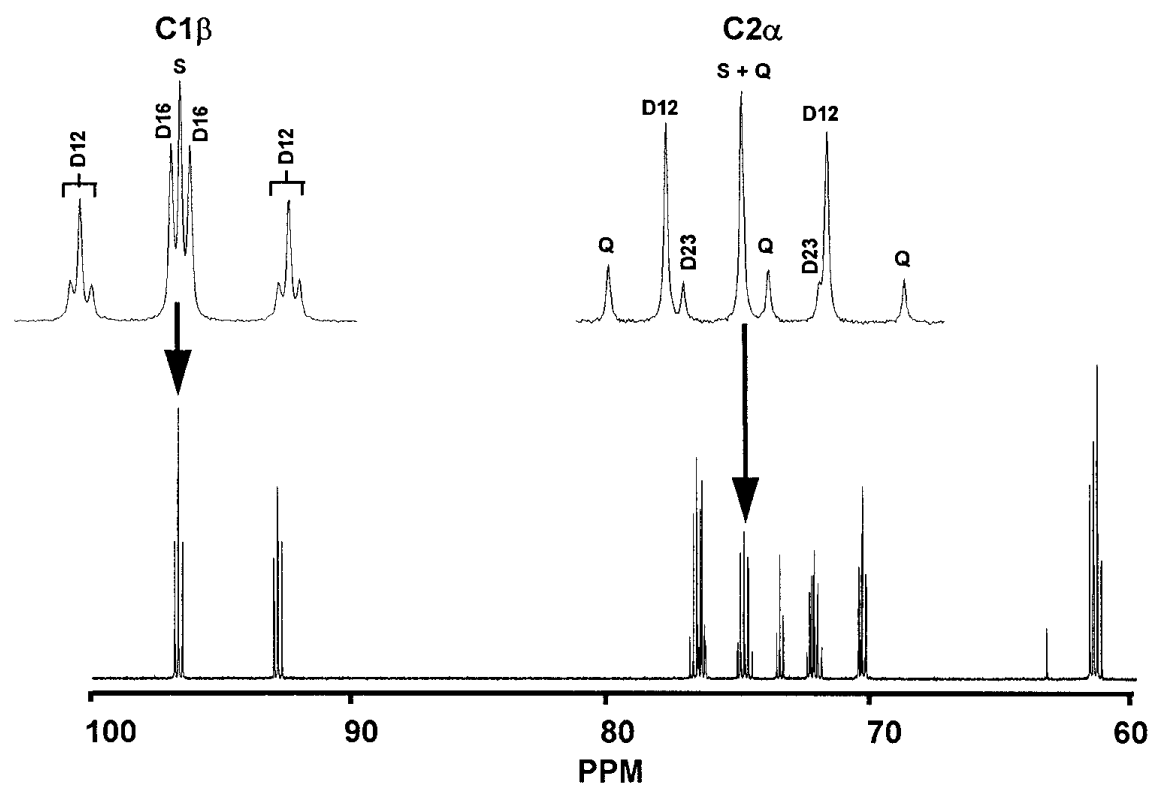

FIG. 1. ${ }^{13} \mathrm{C}$ NMR spectra of plasma glucose obtained from $2 \mathrm{ml}$ of blood taken from a rat infused with $96 \%\left[1,6-{ }^{13} \mathrm{C}_{2}\right]$ glucose plus unlabeled propionate (a) and a rat infused with $\left[1,6-{ }^{13} \mathrm{C}_{2}\right]$ glucose plus $\left[\mathrm{U}-{ }^{13} \mathrm{C}\right]$ propionate (b). Spectra (a) and (b) represent the sum of 256 and 2000 free-induction decays, respectively. In the insets, S, singlet resonance; D16, doublet from coupling of carbon 1 with carbon 6; D12, doublet from coupling of carbon 1 with neighboring carbon 2; D23, doublet arising from the coupling of carbon 2 with neighboring carbon 3; Q, doublet of doublets, or quartet, arising from coupling of carbon 2 with both its neighbors.

measured from a single blood sample. One approach previously used was to choose a stable isotope for one of the tracers and a radioactive tracer for the other (13), but radioactive tracers cannot be used for routine human dinical studies. Using stable isotopes for tracing both pathways presents a significant analytical challenge for separating the contribution of each pathway. Deutera- tion and ${ }^{13} \mathrm{C}$ enrichments of glucose can be measured in a single plasma glucose sample by GC/MS, allowing contributions from separate ${ }^{13} \mathrm{C}$ - and ${ }^{2} \mathrm{H}$-tracers to be resolved $(11,19,20)$. However, these methods require considerable analytical expertise since they involve synthesis of different glucose derivatives whose mass isotopomer distributions must then be subtracted from one another. 


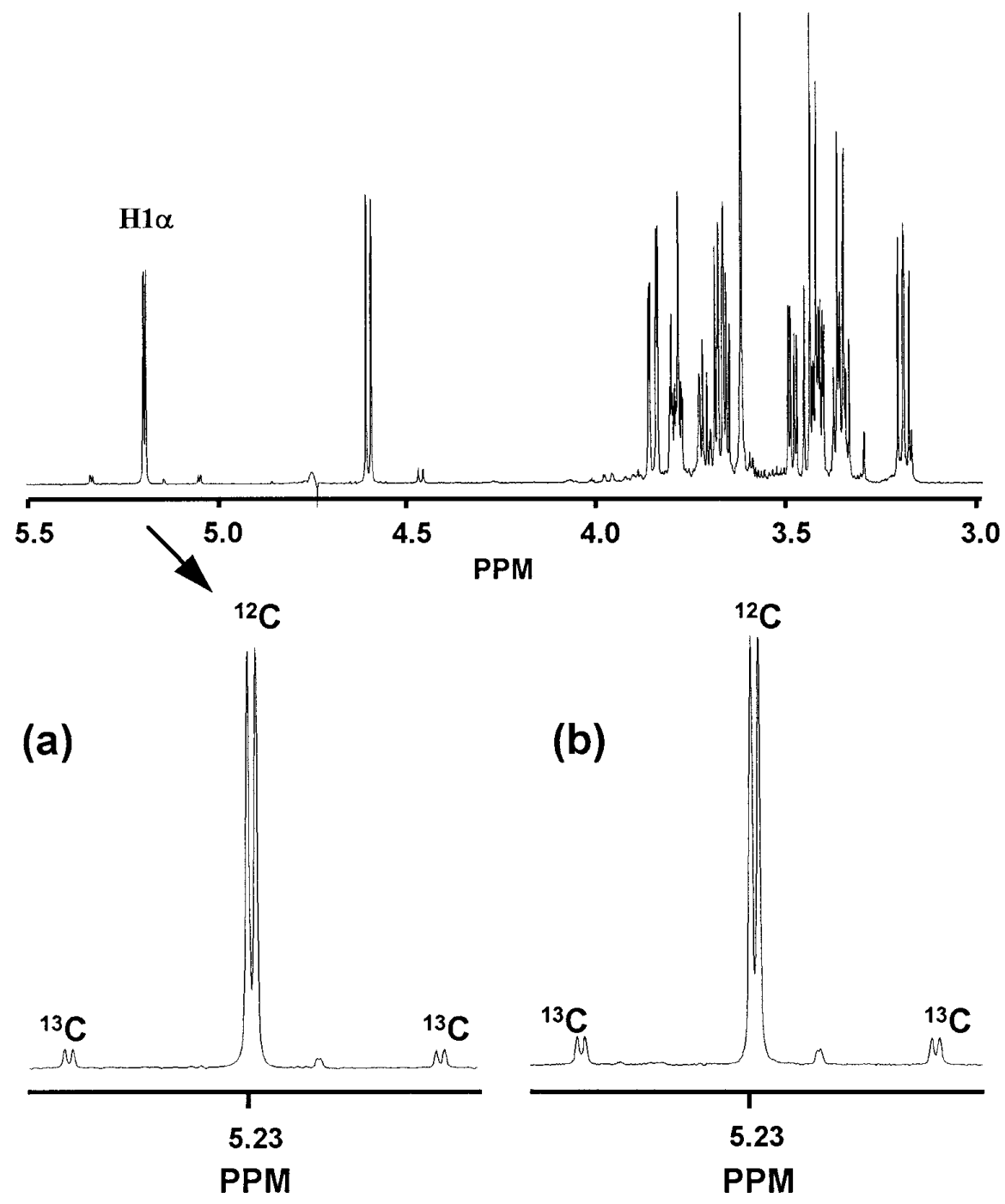

FIG. 2. ${ }^{1} \mathrm{H}$ NMR spectrum of a plasma glucose extract obtained from a rat infused with $\left[1,6-{ }^{13} \mathrm{C}_{2}\right]$ glucose plus unlabeled propionate. Spectrum represent the sum of 32 free-induction decays. The $\mathrm{H} 1 \alpha$ signal is expanded below (a), and for comparison, an expanded $\mathrm{H} 1 \alpha$ signal of a sample obtained from a rat infused with both tracers is also shown (b). ${ }^{12} \mathrm{C}$, signal from protons attached to ${ }^{12} \mathrm{C} 1 \alpha$; ${ }^{13} \mathrm{C}$, signal from protons attached to ${ }^{13} \mathrm{C} 1 \alpha$.

Here we present an alternative approach for simultaneously measuring hepatic glucose production and citric acid cycle metabolism by a simple NMR analysis of plasma glucose using a novel tracer of glucose carbon turnover, $\left[1,6-{ }^{13} C_{2}\right]$ glucose, in combination with a uniformly enriched gluconeogenic substrate, $\left[\mathrm{U}-{ }^{13} \mathrm{C}\right]$ propionate. As with $\left[\mathrm{U}-{ }^{13} \mathrm{C}\right]$ glucose, the connectivity between carbons 1 and 6 of $\left[1,6-{ }^{13} C_{2}\right]$ glucose is broken following metabolism to the level of aldolase or entry into the pentose cycle. However, unlike $\left[\mathrm{U}-{ }^{13} \mathrm{C}\right] \mathrm{glucose}$, neither $\left[1,6-{ }^{13} \mathrm{C}_{2}\right]$ glucose or its recycled products $\left(\left[1^{-13} \mathrm{C}\right]-\right.$ glucose and $\left[6-{ }^{13} \mathrm{C}\right.$ ]glucose) interfere with the numerous multiply enriched glucose isotopomers generated from metabolism of $\left[\mathrm{U}-{ }^{13} \mathrm{C}\right]$ propionate. Since the connectivity between carbons 1 and 6 is detectable by ${ }^{13} \mathrm{C}$
NMR, (21) this provides a basis for measuring the amount of intact $\left[1,6-{ }^{13} \mathrm{C}_{2}\right]$ glucose within the complex isotopomer mixture.

\section{METHODS}

Rats weighing 250-300 g were fasted for $24 \mathrm{~h}$, and the jugular vein was cannulated under ketamine/xylazine anesthesia. Animals were then infused for $120 \mathrm{~min}$ with an aqueous mixture of propionate and $96 \%\left[1,6-{ }^{13} \mathrm{C}_{2}\right]-$ glucose ( 25.00 and $2.75 \mu \mathrm{mol} / \mathrm{Kg} / \mathrm{min}$, respectively) following a prime of $20 \mu \mathrm{mol} 96 \%\left[1,6-{ }^{13} \mathrm{C}_{2}\right.$ ]glucose (Cambridge I sotopes, Cambridge, MA). This amount represents about $11 \%$ of the rat's caloric requirement over duration of the infusion (22); $9 \%$ from propionate and $2 \%$ 


\section{TABLE 1}

Relative and Absolute Hepatic Metabolic Flux Estimates from 24-h Fasted Rats Infused with $\left[1,6-{ }^{13} \mathrm{C}_{2}\right]$ Glucose and $\left[\mathrm{U}-{ }^{13} \mathrm{C}\right]$ Propionate

\begin{tabular}{lcc}
\hline Pathways & Relative flux & $\begin{array}{r}\text { Absolute flux } \\
(\mu \mathrm{mol} / \mathrm{min} / \mathrm{kg})\end{array}$ \\
\hline Anaplerosis & $4.00 \pm 0.57$ & $295 \pm 27$ \\
PK + ME + CC & $2.47 \pm 0.41$ & $182 \pm 25$ \\
Gluconeogenesis & & \\
$\quad$ (Triose units) & $1.53 \pm 0.21$ & $112 \pm 4$ \\
(Hexose units) & $0.76 \pm 0.11$ & $56 \pm 2$ \\
Citrate synthase & 1.00 & $74 \pm 12$ \\
\hline
\end{tabular}

from glucose. The $\left[1,6-{ }^{13} \mathrm{C}_{2}\right]$ glucose enrichment was verified by ${ }^{1} \mathrm{H}$ and ${ }^{13} \mathrm{C}$ NMR batch analysis of the tracer. Animals either received a mixture containing $\left[1,6-{ }^{13} C_{2}\right]-$ glucose and unlabeled propionate $(n=6)$ or a mixture containing $\left[1,6-{ }^{13} \mathrm{C}_{2}\right]$ gl ucose and $\left[\mathrm{U}-{ }^{13} \mathrm{C}\right]$ propionate $(\mathrm{n}=$ 6). At the end of the infusion, $2 \mathrm{ml}$ of blood was drawn from the carotid artery and the animal was sacrificed. Blood was immediately centrifuged and the plasma was deproteinized with perchloric acid. Following neutralization by $\mathrm{KOH}$, the plasma extract was desalted using a mixed-bed ion-exchange resin and then lyophilized and redissolved in $600 \mu / \mathrm{D}_{2} \mathrm{O}$. Proton decoupled ${ }^{13} \mathrm{C} N M R$ spectra of extracts were obtained using a $5-\mathrm{mm}$ broadband probe in a Varian I nova 14.1 T spectrometer operating at $150.9 \mathrm{MHz}$. ${ }^{1} \mathrm{H}$ NMR spectra were obtained with the same spectrometer at $600 \mathrm{MHz}$ using a 5-mm indirect probe. Long-range couplings between ${ }^{13} \mathrm{C}$-carbons 2-6 and $\mathrm{Hl} \alpha$ were abolished by the application of a narrowband WAL TZ-16 ${ }^{13} \mathrm{C}$-decoupling pulse sequence covering the 60-75 ppm region of the ${ }^{13} \mathrm{C}$ NMR spectrum.

To assess the sensitivity of $\left[1,6-{ }^{13} C_{2}\right]$ glucose quantitation by NMR, a set of standards consisting of 12.5 $\mu \mathrm{mol}$ of glucose and containing different ratios of natural abundance and $96 \%\left[1,6-{ }^{13} \mathrm{C}_{2}\right]$ glucose in $0.6 \mathrm{ml}$ of $99 \% \mathrm{D}_{2} \mathrm{O}(\mathrm{pD}=7.0)$ were prepared. The relative areas and intensities of all ${ }^{1} \mathrm{H}$ and ${ }^{13} \mathrm{C} N M R$ spectra were quantitated by a curve-fitting program (NUTS; Acorn NMR, Fremont, CA).

Citric acid cycle fluxes were calculated from the analysis of the glucose C2 multiplet as previously described (16).

\section{RESULTS AND DISCUSSION}

Figure la shows the ${ }^{13} \mathrm{C}$ resonances of glucose from the plasma extract of a rat infused with $\left[1,6-{ }^{13} C_{2}\right]-$ glucose and unlabeled propionate. The $\mathrm{C} 1 \beta$ resonance of $\left[1,6-{ }^{13} \mathrm{C}_{2}\right]$ glucose is split into a doublet $\left(\mathrm{J}_{\mathrm{C} 1-\mathrm{C} 6}=4.3\right.$ $\mathrm{Hz}$ ) (21), enabling it to be distinguished from both the background natural-abundance ${ }^{13} \mathrm{C}$ signal and any $\left[1-{ }^{13} \mathrm{C}\right]$ glucose produced from recycling of the label via the Cori cycle. This pathway does not generate signif- icant levels of $\left[1,6-{ }^{13} C_{2}\right]$ glucose because of the high dilution by unenriched endogenous carbons. Although carbons 2-5 of glucose can also become labeled following randomization of the ${ }^{13} \mathrm{C}$-label by the hepatic citric acid cycle, the dilution is such that there is no significant probability of producing additional multiply enriched glucose isotopomers. As a consequence, the glucose $C 2 \beta$ resonance does not contain significant contributions from ${ }^{13} \mathrm{C}-{ }^{13} \mathrm{C}$ spin-coupled multiplets under these conditions.

The ${ }^{13} \mathrm{C} N M R \mathrm{C} \beta$ resonance of glucose reports the fractional contribution of $\left[1,6-{ }^{13} \mathrm{C}_{2}\right]$ glucose to the subpopulation of glucose molecules enriched in $\mathrm{Cl}$ (69\% in this instance). The well-resolved $\mathrm{H} 1 \alpha$ resonance from the ${ }^{1} \mathrm{H}$ NMR spectrum of the same sample (Fig. 2a) reports the fractional contribution of the $\mathrm{Cl}$-enriched subpopulation (7\% in this instance) to the total glucose pool. Hence, the product of the two measurements $(0.69 \times 0.07)$ gives the fractional contribution of $\left[1,6-{ }^{13} C_{2}\right]-$ glucose to the total glucose pool (0.048). This represents a dilution of $\sim 20$-fold from the $96 \%$-enriched $\left[1,6-{ }^{13} \mathrm{C}_{2}\right]$ glucose infused into the animal. The glucose turnover is simply this dilution of $\left[1,6-{ }^{13} C_{2}\right]$ glucose multiplied by the infusion rate.

When both $\left[1,6-{ }^{13} \mathrm{C}_{2}\right]$ glucose and $\left[\mathrm{U}-{ }^{13} \mathrm{C}\right]$ propionate are infused, the resulting glucose ${ }^{13} \mathrm{C}$ NMR spectrum is much more complex (Fig. 1b), reflecting the additional contribution of $\mathrm{Cl}$ glucose isotopomers from the gluconeogenic metabolism of $\left[\mathrm{U}-{ }^{13} \mathrm{C}\right]$ propionate. Infusion of $\left[U-{ }^{13} \mathrm{C}\right]$ propionate contributed about $5-6 \%$ additional ${ }^{13} \mathrm{C}$-enrichment to the carbon 1 of glucose. The D16 signal remained well-resolved, with most of the additional signal is in the form of D12 multiplets, representing contributions from 2,3- and 1,2,3-labeled triose units (16). This would be also true for other uniformly enriched gluconeogenic precursors such as $\left[\mathrm{U}-{ }^{13} \mathrm{C}\right.$ ]lactate $(13,18)$. We have previously shown that of the triose phosphate isotopomers generated from $\left[\mathrm{U}-{ }^{13} \mathrm{C}\right.$ ]propionate metabolism, more than $85 \%$ are labeled as [2,3]- or $[1,2,3]$ triose phosphates (16). These will generate $[1,2,5,6]-,[1,2,3,4,5,6]-,[1,2,4,5,6]-$, and $[1,2,3,5,6]$ hexose isotopomers, which though labeled in both 1 and 6 , do not interfere with the signal from $\left[1,6-{ }^{13} \mathrm{C}_{2}\right]$ glucose because of additional coupling between carbons 1 and 2. Hexose isotopomers that do interfere are those formed from the combination of $\left[3-{ }^{13} \mathrm{C}\right]$ dihydroxyacetone phosphate with all glyceraldehyde 3-phosphate molecules labeled at C3. Given that $\left[3-{ }^{13} \mathrm{C}\right.$ ]triose phosphate isotopomers make up $15 \%$ of the total C3 isotopomer population and a C3 triose phosphate enrichment of $7 \%$, the probability of forming this set of isotopomers will be $(0.15 \times 0.07) \times 0.07=$ $0.0735 \%$. This represents about $1 / 70$ th (or less than $1.5 \%)$ of the plasma $\left[1,6-{ }^{13} \mathrm{C}_{2}\right]$ glucose enrichment in these experiments. 


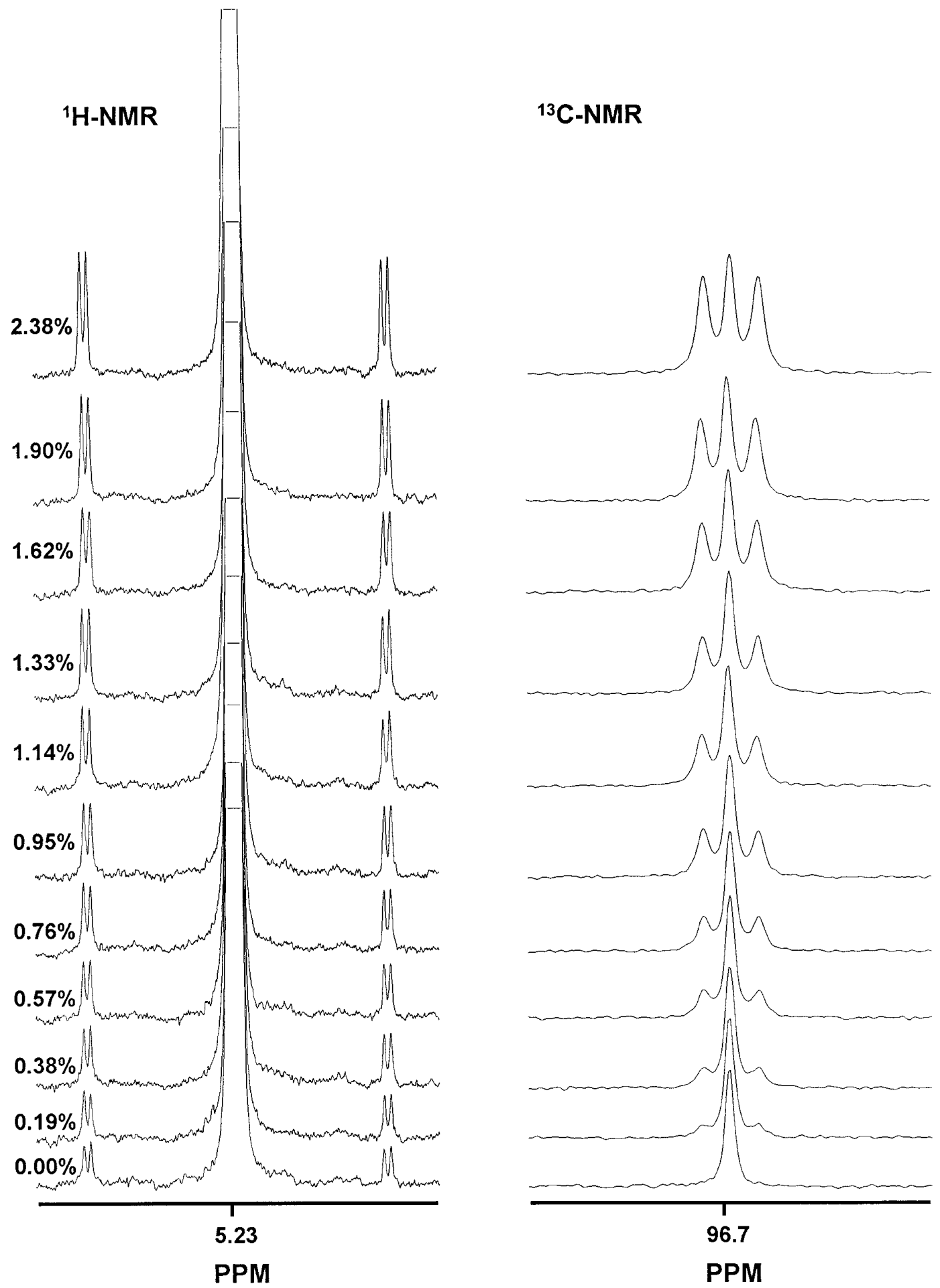

FIG. 3. Stack plots of $\mathrm{C} 1 \beta$ and $\mathrm{H} 1 \alpha$ resonances from a series of glucose standards where the enrichment of $\left[1,6-{ }^{13} \mathrm{C}_{2}\right]$ glucose ranged from 0.0 to $2.4 \%$. Notations are the same as those used in the previous figures. Each ${ }^{13} \mathrm{C}$ and ${ }^{1} \mathrm{H}$ NMR spectrum represents the sum of 2048 and 64 free-induction decays, respectively.

The presence of additional ${ }^{13} \mathrm{C}$ in position 1 of glucose following gluconeogenic metabolism of $\left[\mathrm{U}-{ }^{13} \mathrm{C}\right]$ propionate results in a smaller D16 contribution to the
$\mathrm{C} 1 \beta$ resonance in the ${ }^{13} \mathrm{C}$ NMR spectrum. However, this is balanced by an increase in the fraction of $\mathrm{Cl}$ enriched glucose molecules (Fig. 2b); hence, the esti- 
mate of the $\left[1,6-{ }^{13} \mathrm{C}_{2}\right]$ glucose fraction is consistent with that of the previous experiment.

As expected, hepatic glucose production estimates in animals infused with unlabeled versus labeled propionate was identical (53 \pm 4 and $56 \pm 2 \mu \mathrm{mol} / \mathrm{kg} / \mathrm{min}$ ). These values are in good agreement with previous measurements of glucose turnover in overnight-fasted rats (8). In animals where both glucose and propionate tracers were given, isotopomer analysis of the C2 multiplet provided relative gluconeogenic flux measurements. The relative areas of the multiplet components were $\mathrm{C} 2 \mathrm{~S}=0.24 \pm 0.02 ; \mathrm{C} 2 \mathrm{D} 12=0.45 \pm 0.01$; $\mathrm{C} 2 \mathrm{D} 23=0.09 \pm 0.01 ;$ and $\mathrm{C} 2 \mathrm{Q}=0.23 \pm 0.01$, yielding the relative flux measurements of anaplerosis, OAApyruvate recycling and net gluconeogenesis shown in Table 1 . These values are similar to those obtained from our recent study where $\left[U-{ }^{13} \mathrm{C}\right]$ propionate was the only tracer provided (16). This indicates that the presence of $\left[1,6-{ }^{13} C_{2}\right]$ glucose or its metabolic products did not influence the gluconeogenic flux measurements derived from $\left[\mathrm{U}^{13} \mathrm{C}\right.$ ]propionate metabolism.

In 24-h fasted rats, hepatic glycogen content has been reported to be $0.7-1.3 \mu \mathrm{mol} / \mathrm{g}$ liver (5.6-10.4 $\mu \mathrm{mol} / 275 \mathrm{~g}$ rat) (23). Given a cumulative glucose production of $\sim 1850 \mu \mathrm{mol} / \mathrm{rat}$ over the 2 -h infusion period, the maximal contribution of glycogenolysis over this period is $10.6 / 1850$, or $0.57 \%$ of the total glucose turnover. Based on substrate balance studies, the maximal contribution of glycerol to hepatic glucose output in 24-h fasted rats is about 5\% (24). Since the citric acid cycle is supplying the remaining $90-95 \%$ of glucose carbons, glucose turnover (expressed as triose units) is a good approximation for the absolute rate of PEP synthesis from the hepatic citric acid cycle. Combining this information with the isotopomer output from the glucose C2 analysis provides absolute flux estimates for hepatic anaplerosis, combined recycling through pyruvate kinase, malic enzyme, and Cori cycle (PK + $\mathrm{ME}+\mathrm{CC}$ ) and citrate synthase pathways (see Table 1).

The practical lower limit of $\left[1,6-{ }^{13} \mathrm{C}_{2}\right]$ glucose quantitation by NMR in a clinically relevant sample was tested with a set of standards consisting of known mixtures of natural-abundance and $99 \%\left[1,6-{ }^{13} \mathrm{C}_{2}\right]-$ glucose fraction. The amount of glucose $(12.5 \mu \mathrm{mol})$ represents a typical amount extracted from a 10-ml human blood sample following centrifugation, deproteinization, and lyophilization ( $\mathrm{J}$ ones et al., unpublished observations). Figure 3 shows the ${ }^{13} \mathrm{C}$ and ${ }^{1} \mathrm{H}$ NMR spectra of $\mathrm{C} 1 \beta$ and $\mathrm{H} 1 \alpha$ glucose resonances for these samples. Acceptable signal-to-noise levels were achieved with $\left[1,6-{ }^{13} \mathrm{C}_{2}\right.$ ]glucose fractions ranging from 0.25 to $2.50 \%$ using a total collection time of under $2.5 \mathrm{~h}$ per sample $\left(\sim 2 \mathrm{~h}\right.$ for the ${ }^{13} \mathrm{C} N M \mathrm{R}$ spectrum and $\sim 15 \mathrm{~min}$ for the ${ }^{1} \mathrm{H}$ NMR spectrum). The data provide a precise and accurate correlation between the experimentally measured and real $\left[1,6-{ }^{13} C_{2}\right]-$

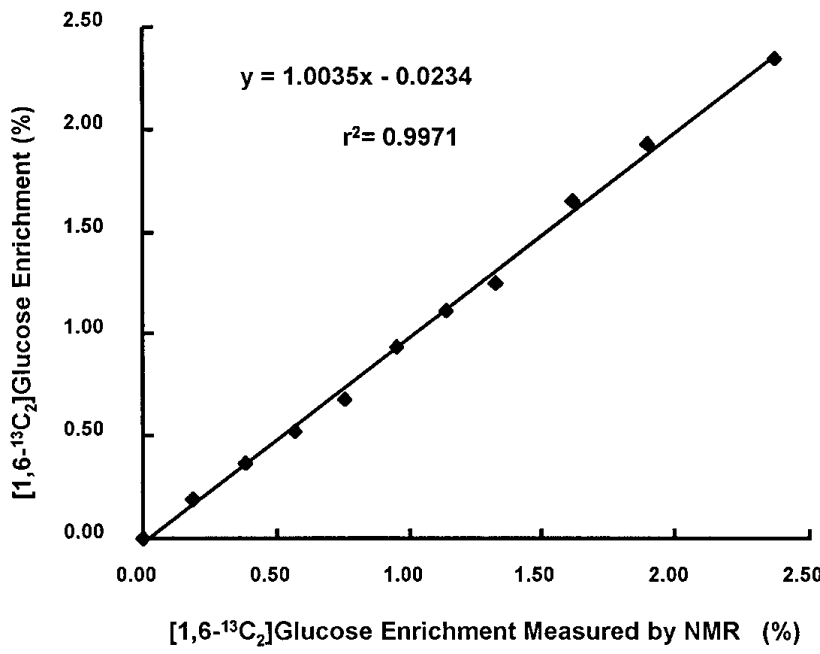

FIG. 4. Comparison of $\left[1,6-{ }^{13} C_{2}\right]$ glucose fractional enrichment measurement by NMR analysis vs the real composition of the standards. Error bars represent the standard deviation of four sets of measurements.

glucose fraction (Fig. 4). The $0.5 \%$ enrichment level can be attained in a 70-kg human with a basal glucose turnover of $2 \mathrm{mg} / \mathrm{kg} / \mathrm{min}$ using a total of $\sim 170$ $\mathrm{mg}\left[1,6-{ }^{13} \mathrm{C}_{2}\right] \mathrm{glucose}(0.01 \mathrm{mg} / \mathrm{min} / \mathrm{kg}$ infusion for $3 \mathrm{~h}$ following a prime of $40 \mathrm{mg}$ ).

Quantitation of tracer levels of $\left[\mathrm{U}-{ }^{13} \mathrm{C}\right]$ glucose by ${ }^{13} \mathrm{C}$ NMR in human subjects was demonstrated almost 10 years ago by Brainard et al. (25). Despite this, NMR has not been widely used for glucose turnover measurements with this tracer because the parent $m+6$ tracer molecule can be reliably quantitated by GC-MS, a less expensive and more sensitive method. For the $m+6$ measurement, positional isotopomer information is re dundant; hence, the advantages of ${ }^{13} \mathrm{C}$ NMR in determining positional labeling information are nullified. However, for accurately determining the composition of a complex mixture of glucose isotopomers that contain fewer than six ${ }^{13} \mathrm{C}$-atoms, positional information is crucial. GC-MS methods extract positional information by systematic fragmentation of the molecule and analysis of the constituent mass isotopomers. This approach is very challenging for the analysis of glucose ${ }^{13} \mathrm{C}$-isotopomers since it involves the preparation and mass isotopomer analysis of multiple derivatives (26). In contrast, most ${ }^{13} \mathrm{C}$ NMR measurements have focused on the quantitation of local clusters of positional isotopomers, such as the triose units of glucose, by taking advantage of nearest-neighbor ${ }^{13} \mathrm{C}-{ }^{13} \mathrm{C}-$ spinspin coupling $(16,27-29)$. Consideration of long-range coupling interactions significantly expands the number of different ${ }^{13} \mathrm{C}$-isotopomers that can be quantitated by NMR, providing the opportunity to design more complex and informative labeling experiments. 


\section{ACKN O WLEDGMENTS}

This research was supported by grants from the NIH (P41RR02584) and a PhD grant from J NICT, Portugal, awarded to R.A.C. (BD-3604/94).

\section{REFERENCES}

1. Esenmo, E., Chandramouli, V., Schumann, W. C., Kumaran, K., Wahren, J ., and Landau, B. R. (1992) Am. J . Physiol. 263(1, Pt. 1), E36-E41.

2. Tayek, J. A., and Katz, J . (1996) Am. J . Physiol. 270(4, Pt. 1), E 709-E 717.

3. Tayek, J. A., and Katz, J . (1997) Am. J. Physiol. 272(3, Pt. 1), E476-E 484.

4. Peroni, O., Large, V., Odeon, M., and Beylot, M. (1996) Metabolism 45, 897-901.

5. Frazer, T. E., Karl, I. E., Hillman, L. S., and Bier, D. M. (1981) Am. J . Physiol. 240, E615-E621.

6. Martineau, A., Lecavalier, L., Falardeau, P., and Chiasson, J . L. (1985) Anal. Biochem. 151, 495-503.

7. Lee, W. N., Sorou, S., and Bergner, E. A. (1991) Biochem. Med. Metab. Biol. 45, 298-309.

8. Katz, J., Dunn, A., Chenoweth, M., and Golden, S. (1974) Biochem. J . 142, 171-183.

9. Katz, J ., Golden, S., Dunn, A., and Chenoweth, M. (1976) Hoppe Seylers. Z. Physiol. Chem. 357, 1387-1394.

10. Dunn, A., Katz, J ., Golden, S., and Chenoweth, M. (1976) Am. J . Physiol. 230, 1159-1162.

11. Hellerstein, M. K., Neese, R. A., Linfoot, P., Christiansen, M., Turner, S., and Letscher, A. (1997) J . Clin. Invest. 100, 13051319.

12. Landau, B. R., Chandramouli, V., Schumann, W. C., Ekberg, K., Kumaran, K., Kalhan, S. C., and Wahren, J . (1995) Diabetologia 38, 831- 838.

13. Katz, J ., Wals, P., and Lee, W. N. (1993) J. Biol. Chem. 268, 25509-25521.
14. Di Donato, L., Des Rosiers, C., Montgomery, J. A., David, F., Garneau, M., and Brunengraber, H. (1993) J . Biol. Chem. 268, 4170- 4180.

15. Landau, B. R., Schumann, W. C., Chandramouli, V., Magnusson, I., Kumaran, K., and Wahren, J. (1993) Am. J . Physiol. 265, E636-E647.

16. J ones, J . G., Naidoo, R., Sherry, A. D., J effrey, F. M., Cottam, G. L., and Malloy, C. R. (1997) FEBS Lett. 412, 131-137.

17. Magnusson, I., Schumann, W. C., Bartsch, G. E., Chandramouli, V., Kumaran, K., Wahren, J ., and Landau, B. R. (1991) J . Biol. Chem. 266, 6975- 6984.

18. Des Rosiers, C., Di Donato, L., Comte, B., Laplante, A., Marcoux, C., David, F., Fernandez, C. A., and Brunengraber, H. (1995) J . Biol. Chem. 270, 10027-10036.

19. Kalhan, S. C., Bier, D. M., Savin, S. M., and Adam, P. A. (1980) J . Clin. Endocrinol. Metab. 50, 456-460.

20. Previs, S. F., Ciraolo, S. T., Fernandez, C. A., Beylot, M., Agarwal, K. C., Soloviev, M. V., and Brunengraber, H. (1994) Anal. Biochem. 218, 192-196.

21. Walker, T. E., London, R. E., Whaley, T. W., Barker, R., and Matwiyoff, N. A. (1976) J .A.C.S. 98, 5807-5813.

22. National Research Council (1972) Nutrient Requirements of Laboratory Animals, 2nd ed., Vol. 10, NRC, Washington, DC.

23. Katz, J ., Wals, P., and Lee, W. N. (1991) Proc. Natl. Acad. Sci. USA 88, 2103-2107.

24. Remesy, C., and Demigne, C. (1983) Ann. Nutr. Metab. 27, 5770.

25. Brainard, J. R., Downey, R. S., Bier, D. M., and London, R. E. (1989) Anal. Biochem. 176, 307-312.

26. Beylot, M., Previs, S. F., David, F., and Brunengraber, H. (1993) Anal. Biochem. 212, 526-531.

27. Cline, G. W., and Shulman, G. I. (1995) J . Biol. Chem. 270, 28062-28067.

28. Cohen, S. M. (1987) Biochemistry. 26, 581-589.

29. J ones, J. G., Cottam, G. L., Miller, B. C., Sherry, A. D., and Malloy, C. R. (1994) Anal. Biochem. 217, 148-152. 